\title{
THE IMPLEMENTATION OF EARLY INITIATION OF BREASTFEEDING AND THE SUCKING REFLEX IN NEWBORNS
}

\author{
Ermiati, Restuning Widiasih, Anita Setyawati \\ Faculty of Nursing, Universitas Padjadjaran, Bandung, Indonesia \\ Correspondence: ermiati@unpad.ac.id
}

\begin{abstract}
Early initiation of breastfeeding (IMD) is a program recommended by the government in increasing the breastfeeding success, achieving exclusive breastfeeding and reducing the infant mortality rates. The IMD is a process of mothers initiates breastfeeding within one hour after delivery of their baby. During an hour, the baby looks for his mother's nipples without help. This would be useful to increase the ability of the baby's sucking reflex. The IMD is implemented in the delivery room as part of the APN procedure, however limited study in Indonesia assessed the IMD procedure. This study is aimed to assess the implementation of IMD and the sucking reflect of newborns in a hospital in Bandung city. This design of the study was the quantitative descriptive approach. The samples were 30 newborns. The samples were chosen using the accidental sampling technique. There were two types of instruments which are an observation sheet to check the procedure of IMD, and an instrument to assess babies' sucking reflex including rooting, sucking, and swallowing reflexes. The study findings described in a frequency distribution. This study found that $100 \%$ of deliveries were carried out IMD inappropriately, and $86.7 \%$ of babies' sucking reflects were not achieved. The study concluded that the implementation of IMD was not maximal, and would be affected babies had not succeeded in breastfeeding. It is expected that the hospital would implement IMD as the standard of maternity services.
\end{abstract}

Keywords: Early Breastfeeding Initiation, Reflect

\section{INTRODUCTION}

According to the World Health Organization (WHO) almost all of the five million neonatal deaths $(98 \%)$ have occurred in developing countries including Indonesia. The data showed that around two-thirds of these deaths occurred in the early neonatal period. $42 \%$ of neonatal deaths were caused by infection (Chair, 2007). Reducing the neonatal mortality rates is crucial, as the neonatal (0-28 days) mortality contributed $59 \%$ of the infant (< 1 year) deaths (IMR) (Ministry of Health, RI. 2017)

Providing an appropriate management is needed to reduce the IMRs. One of the methods for reducing IMR is applied the IMD. IMD or early initiation of breastfeeding is the process of mothers initiates breastfeeding for one hour after delivery of their baby. 
Baby suckling immediately after birth (Maryunani, 2012). In the IMD process, the baby was given the opportunity related to the use of reflexes and instincts. The normal baby should have the ability to suck, and the baby would use their instinct which the baby suck strongly, even though, still trained (Bobak, 2012). Breastfeeding in a newborn is a combination of three infant reflexes that are reflex of rooting, sucking reflex and swallowing reflex. One of the most important actions for babies to maintain life and fulfill their nutrition is by doing sucking movements and swallowing movements when feeding (Maryunani, 2012).

The hospital $\mathrm{XX}$ is a military hospital, that provides health services to members of the military, army, civil servants, families and also the community. One of the services provided is normal delivery care. There is a normal delivery care standard procedure in Indonesia namely the APN procedure. The APN consists of 60 steps, and there is IMD implementation as part of the APN procedure. In the APN, skin to skin contact between mother and baby for early initiation of breastfeeding (IMD) should performance as part of stage 2 in the labor process, especially after cutting the umbilical cord. Even though this military hospital did not have a specific standard procedure for IMD, they use the APN as the standard of delivery service. Researchers were interested in assessing the implementation of the IMD procedure in The XX hospital and the sucking reflects of newborns. The aimed of this study was to describe the early initiation of breastfeeding and the sucking reflect of newborns in the delivery room.

\section{METHOD}

This design of the study was the quantitative descriptive approach. The samples were 30 newborns. The samples were chosen using the accidental sampling technique. There 
were two types of instruments which are an observation sheet to check the procedure of IMD, and an instrument to assess babies' sucking reflex including rooting, sucking, and swallowing reflexes. The observation includes putting the baby on the mother's chest, skin to skin contact, covering the mother and baby using a blanket at least 1 hour or the baby is able to find nipples and suckle early. The second instrument observed babies' sucking reflexes including rooting, sucking, and swallowing reflexes. Reflexes assessed after 6 hours of labor. Data were analyzed using the frequency distribution and presented in tables.

\section{RESULT}

This section presents these study findings. There are three tables of findings including the characteristic of respondents, the implementation of the IMD procedures, and babies' sucking reflexes.

Table 1 Characteristics of Respondents $(\mathrm{N}=30)$

\begin{tabular}{lcc}
\hline \multicolumn{1}{c}{ Characteristics } & Frequency & Percentage \\
\hline Age & 2 & \\
$20<$ years & 25 & 6,7 \\
$20-35$ year & 3 & 83,3 \\
$>35$ year & & 10 \\
Parity & 16 & 53,3 \\
Primipara & 14 & 46,7 \\
Multipara & & \\
Education & 8 & 26,7 \\
SD/SMP & 12 & 40 \\
SMA & 10 & 33,3 \\
PT & & \\
\hline
\end{tabular}

Table 1 shows that the majority of respondents (83.3\%) mothers aged 20 to 35 years. $53.3 \%$ of them were primiparous mothers, and 12 mothers (40\%) attended a high school education. 
Table 2 Implementation of IMD $(\mathrm{N}=30)$

\begin{tabular}{lcc}
\hline Implementation of IMD & Total & Percentage \\
\hline Appropriate as procedure & 0 & 0 \\
Inappropriate & 30 & 100 \\
\hline Total & 30 & 100 \\
\hline
\end{tabular}

Table 2 present that $100 \%$ of the IMD implementation of IMD was inappropriate. Some health workers did this procedure, other did not practice this procedure. Health workers who applied the procedure were not to follow the standard of procedure.

Table 3 The babies' sucking reflexes (N 30)

\begin{tabular}{ccc}
\hline Reflexes & Total & Percentage \\
\hline Strong sucking & 4 & 13,3 \\
Weak sucking & 26 & 86,7 \\
\hline Total & 30 & 100 \\
\hline
\end{tabular}

Table 3 reveals that the majority of babies $86.7 \%$ had a weak sucking ability.

\section{DISCUSSION}

These study findings showed that all deliveries did not implement the IMD procedure appropriately, especially related to the duration of the IMD which is an hour for the skin to skin contact between baby and mother for IMD. In this study, IMD activities were carried out by health workers only for 5-15 minutes. According to Roesli (2008) IMD is putting the baby on the mother's chest or abdomen immediately after delivery and allowing the baby to look for the mother's nipple and then sucking it at least one hour after birth. The IMD should be done directly as part of the labor process, without 
interfered by other activities such as measuring the baby. This process should be skin to skin between mother and baby (JNPK-KR, 2008).

The health workers' reasons to delay the IMD include considering mother physical conditions such mother exhausted with the delivery process, so health workers prioritized the maternal care. Other reasons were lack of mothers' support of motivation, they preferred to take rest after giving birth rather than having to monitor the baby while doing IMD, and they also assumed that ASI has not come out or not enough for babies.

The IMD is very benefited for babies. The skin to skin contact between mother and babies provide warmth to them, as newborns usually experience cold or hypothermia. Mothers' skin is thermoregulatory for babies. A study that conducted by Dr. Niels Bergman from South Africa found that when the baby had a cold, then the mother's skin temperature rises automatically to overheat babies, next the temperature of the mother's skin, would decrease one degree (Roesli, 2008).

The IMD is a procedure that supports in reducing the infant mortality rates especially under the age of 28 days. If all babies are given the opportunity to feed themselves by skin to skin contact with their mother immediately after born approximately one hour, then one million baby's lives can be saved. This finding is strengthened by the research in Ghana by Dr. Karen Edmond, who involved 10947 babies born, he found that the baby was given the opportunity to suckle and was allowed to make skin-to-skin contact in the first hour after birth, $22 \%$ of the lives of babies under 28 days could be saved. Another finding was the baby started breastfeeding the first two hours, the lives of babies under 28 days can be saved by 
$16 \%$, this means that the risk of infant mortality under the age of 28 days would increase 6 times greater each one hour (Roesli, 2008).

In this study the majority of babies $86.7 \%$ did not have an ability to suck properly during IMD implementation or the sucking reflexes were weak. This may because of the implementation of IMD in the Maternity Room was less than an hour, only 5-15 minutes. In the first 15 minutes, the newborn focused on the faces of his parents and listening to the voice, especially the mother's voice then followed by an active awareness phase. During this active alert period, newborns often make sudden active movements and may they also cry. Babies who have strong sucking reflexes and may look like she or he is hungry, this is a good time to start breastfeeding. (Roesli, 2008). Babies in this study did not experience the fully IMD processes, they only had 515 minutes opportunity skin to skin contact, then health workers cleaned mothers and babies. Health workers were focused on cleaning and disinfected the intra-natal areas such as washing mother, cleaning stuff rather than the IMD. As a result, the IMD implementation had not been carried out as the procedure and the baby had not succeeded in the early breastfeeding.

The intervention that health workers should focus on the IMD implementation including facilitating the improvement of parents and babies relationships, especially mothers. Eye-to-eye contact can be done by delaying the administration of eye medication, so the baby can interact with parents appropriately. Observing signs of a baby's readiness to suckle such as baby voices, yawning, stretching, and mouth movements. Next, moving the hand to the mouth, a rooting reflex arises, moving the head to cry as a sign of early breastfeeding. According to Roesli (2008) babies show readiness to start breastfeeding after 30-40 minutes after birth. 
The IMD in the first 1 hour would increase the potential for successful breastfeeding exclusively for 6 months, as breastmilk fulfill all the nutrition needs of the baby. IMD within one hour after birth is important for reducing infant mortality and reducing many neonatal deaths. Saving 1 million babies begins with one action, which is the IMD in the first hour of birth.

The IMD implementation at The XX hospital had been implemented but the implementation had not been appropriate as the APN and the IMD procedures. The implementation of IMD was only 5-15 minutes only because the newborn baby must be weighed and measured immediately, besides that mother was in the third stage of labor. In this stage health worker needed to push out the placenta and the perineum care when there was a rupture. Those activities were inhibited health workers in facilitating the IMD process, and its influence on babies sucking reflexes abilities. Another burden was no clear regulation like the IMD Standard Operating Procedure (SOP) that regulated by the XX hospital. As a result, the implementation of the IMD procedure was not appropriate and would be affected babies' development and health.

\section{CONCLUSION}

In conclusion, the implementation of IMD was done but less than 1 hour, so the baby had not succeeded in the early breastfeeding because and the IMD activity was stopped and would be affected babies' health. It is expected that the Hospital concern with this issue and develop a standard procedure of the IMD.

\section{REFERENCES}

Bobak, Lowdermilk, Jensen. 2012. Buku Ajar Keperawatan Maternitas. Jakarta: EGC. 
Depkes RI. 2008. Standarisasi Program Kesehatan Ibu, Bayi, Anak, Balita di Indonesia

Chair, I. 2007, Metode Kanguru Untuk Bayi Prematur,http://www.halalguide,com, di akses tanggal Juni 2018

JNPK-KR. 2008. Pelatihan Klinik Asuhan Persalinan Normal, Buku Acuan. Ed.4 revisi. Jakarta: Jaringan Nasional Pelatihan Klinik-Kesehatan Reroduksi.

Kementerian Kesehatan RI. 2017. Profil Kesehatan Indonesia Profil Kesehatan Indonesia Tahun 2016. Jakarta : Kementerian Kesehatan RI.

Maryunani, A. 2012. Inisiasi Menyusu Dini, Asi Ekslusif dan ManajemenLaktasi. Jakarta: TIM.

Roesli, U, 2001. Mengenal ASI Eksklusif Seri I, Trubus Agriwidya, Jakarta.

Roesli, U. 2008. Inisiasi Menyusu Dini Plus ASI Eksklusif. Penerbit Pustaka Bunda. 